\title{
The Fylla structural complex: possible very large gas reserves offshore southern West Greenland
}

\author{
Kevin J. Bate, Richard C. Whittaker, James A. Chalmers \\ and Trine Dahl-.Jensen
}

This paper outlines the evidence for the possible existence of very large gas reserves offshore southern West Greenland. It is a slightly modified version of a paper published in the Oil \& Gas Journal, August 22nd 1994.

Recent interpretation of new seismic data acquired offshore southern West Greenland (Fig. 1) has identified a number of structural leads which may contain gas reserves with a cumulative volume of the order of 100$)$ tel. The presence of two that-spots with clear Amplitude Versus Offset (AVO) effects overlying a possible oil column is the most direct indication of the occurrence of gas in the area.

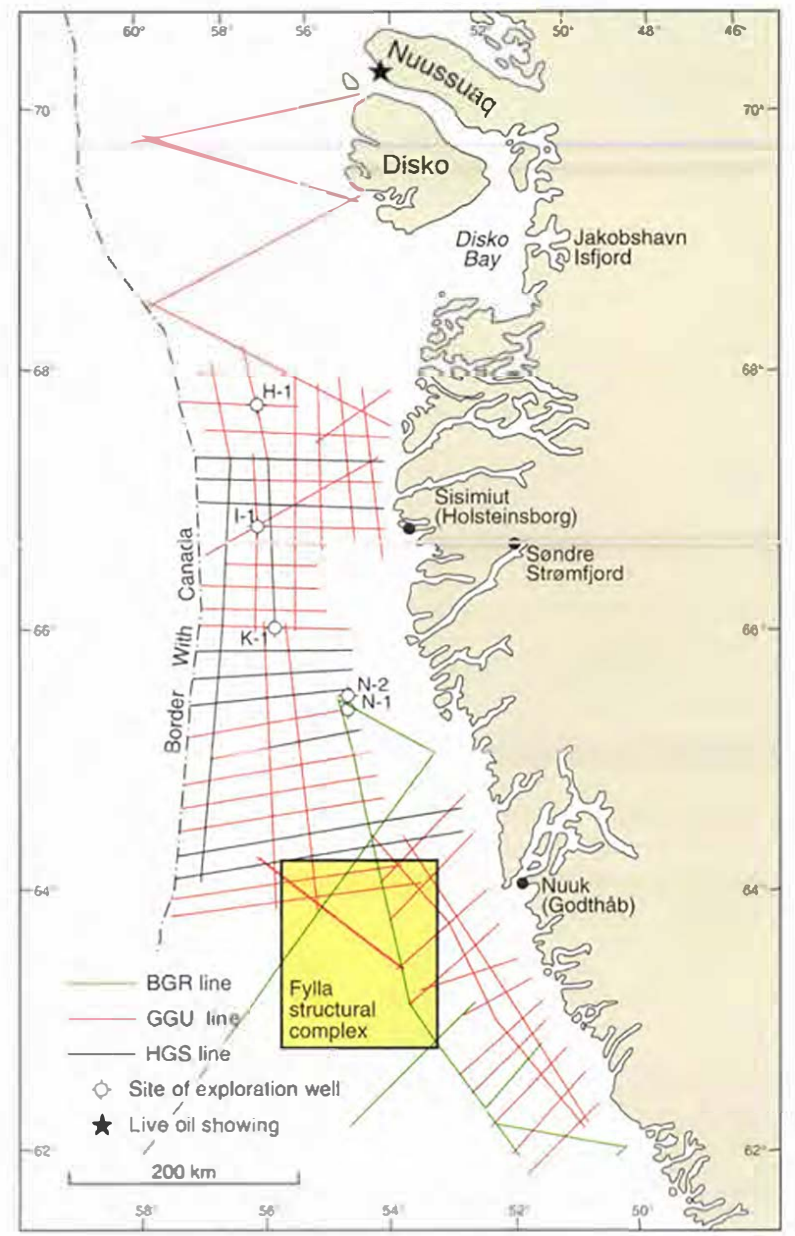

A total of seven individual structural leads have been identified in an area $130 \mathrm{~km} \times 60 \mathrm{~km}$ underlying Fylla Banke, within what has been termed the Fylla structural complex (Fig. 2). All the leads are in the form of large tilted fault blocks created in the Early Tertiary and draped by Paleocenc and Eocene mudstones. Seven seismic lines delineate the leads, two of which are covered by only a single line. Individual fault blocks can be traced into neighbouring. widely-spaced seismic lines suggesting that they are of a large size. The fault blocks are clearly evident on line GGU/92-22 (Fig. 3) through the Fylla structural complex. Water depths range from $200 \mathrm{~m} \mathrm{to} 1500) \mathrm{m}$.

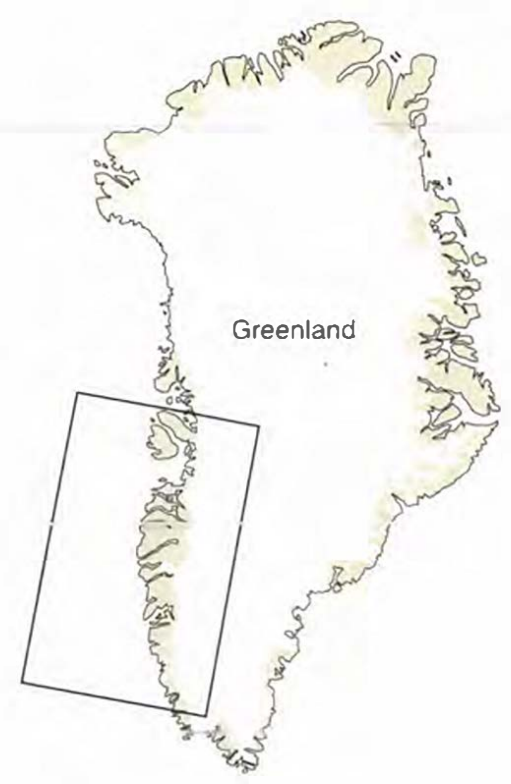

Fig. 1. Location of seismic lines used in a recent assessment of the petroleum prospectivity offshore southern West Greenland. The location of the map of the Fylla structural complex shown in Fig. 2 is indicated by the box. 


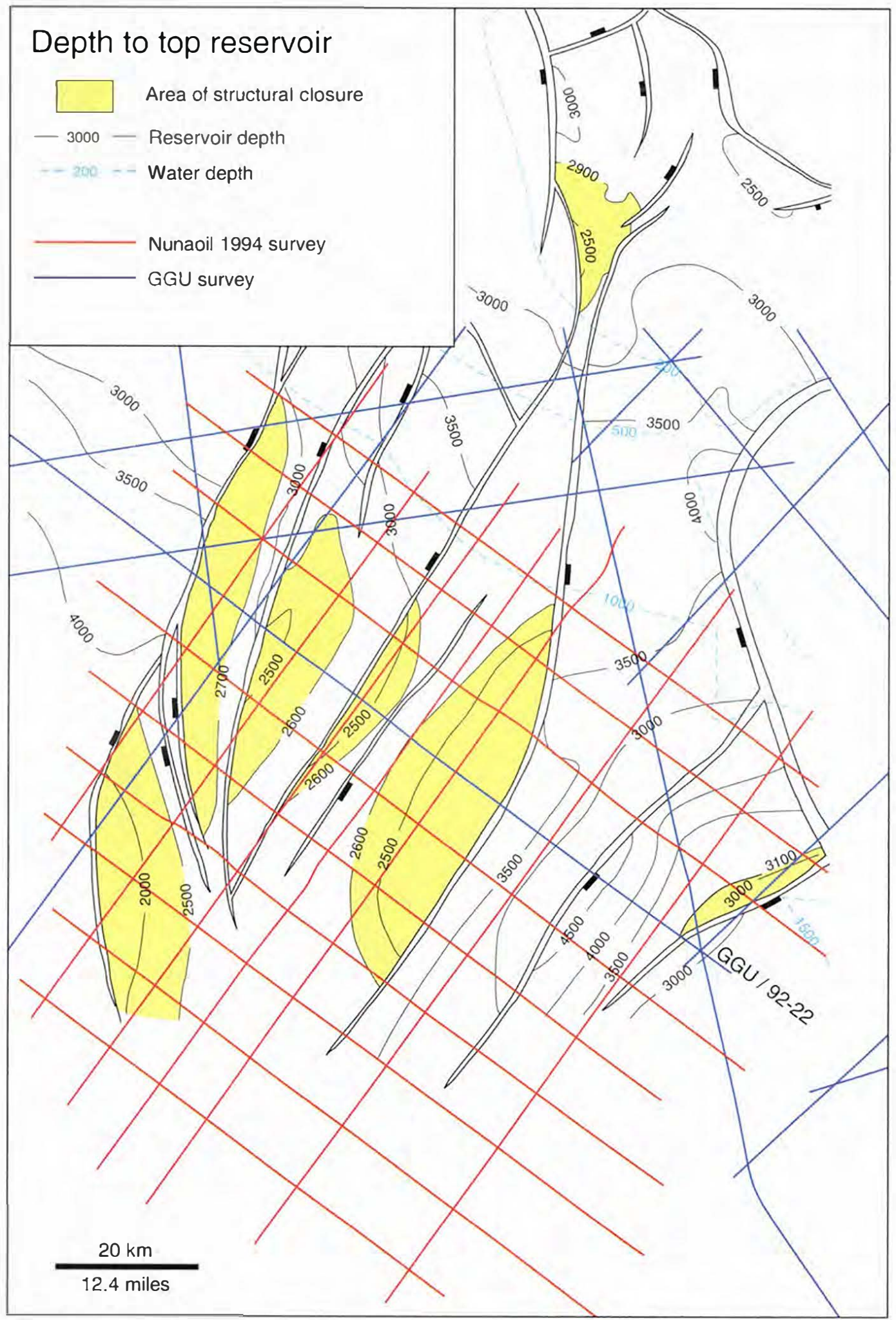

Fig. 2. Map showing depth (o) top reservoir (contour interval $5(0) \mathrm{m}$ ) in the Fylla structural complex based on (iciU) 1990-1992 and older surveys. The north-eastern part of the map is based on interpretation of released industry seismic data from the 1970s. Location of Nunatoil's 1994 seismic lines is also shown. 


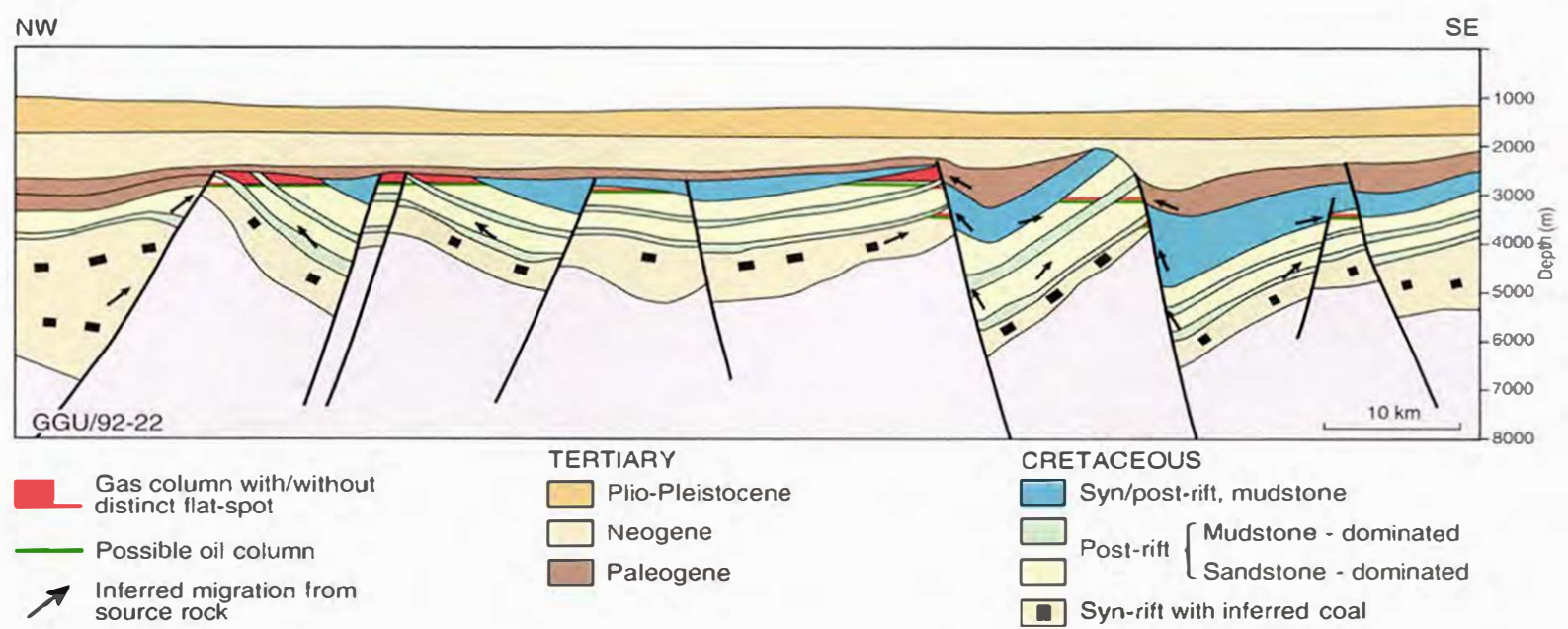

Fig. 3. Depth section through the Fylla structural complex (line GGU/92-22).

\section{Regional geological development}

The geological development of the basins of fishore West Greenland is related to the opening of the Labrador Sea in the Tertiary (Fig. 4: Chalmers et al., 1993). Rifting probably began in the Early Cretaceous and renewed extension in the Paleocene created large fault blocks which extend to the continent-ocean boundary $150 \mathrm{~km}$ seaward of the continental slope (Chalmers, 1991). Active generation of oceanic crust probably began in the Paleocene, but had ceased by the Late Eocene, atter which thermal subsidence dominated.

Knowledge of the sedimentary succession offshore southern West Greenland is based primarily on the results from tive exploration wells drilled in the mid-197()s (Rolle, 1985). Four of these wells terminated in either Paleocene basalts or in Precambrian basement overlain by Lower Tertiary sediments. Only one well, Ikermiut-1. penetrated into the Upper Cretaceous; 850 m of Campanian and Maastrichtian mudstone were intersected before drilling was terminated at a depth of $3619 \mathrm{~m}$. None of the wells were drilled deep enough to test the Cretaceous, and detinition of deeper units is therefore based on seismic character. Interpretation of their age and, to some extent, their lithology is based on comparisons with other areas such as the Labrador Shelf (Balkwill, 1987: Balkwill et al.. 1990); McWhae et al., 1980), and with Lower Cretaceous sediments exposed onshore West Greenland in the DiskoNuussuac area (Fig. 1).

Three sequences have been identified in the deeper section. The deepest, the Kitsissut sequence, has a seismic character which suggests that it is a pre-rift to early syn-rift succession. Analogy with the Labrador Shelf suggests that the Kitsissut sequence may be equivalent to the Lower
Member of the Bjarni Formation of Aptian age, which consists of fluvial and deltaic sandstones, conglomerates and coaly shales. The overlying Appat sequence appears to have been deposited during the main stage of rifting and may be equivalent to the Upper Member of the Bjarni Formation, which consists of sandy mudstones and porous sandstones of Albian age. The Kitsissut and Appat sequences can be demonstrated to be present within structures in the identified leads and are expected to be the most promising reservoir units.

The Appat sequence is overlain by the Kangeq sequence, the upper part of which was intersected in the lowermost $850 \mathrm{~m}$ of the Ikermiut-1 well, where it consists predominantly of marine mudstone (Rolle, 1985). The transparent seismic character of the Kangey sequence suggests that it is homogeneous and hence mudstone-dominated throughout. The lowermost part of the Kangeq sequence is thought to be a correlative of the basal part of the Markland Formation on the Labrador Shelf and hence of Cenomanian to Turonian age. This sequence was probably deposited during a period of thermal subsidence in the Late Cretaceous. but prior to renewed rifting in the Paleocene.

Renewed extension of the crust in the Palencene, possibly related to the initiation of sea floor spreading in the Labrador Seal and strike-slip movement as Greenland moved north relative to North America, resulted in the creation of a second generation of faults (Chalmers et al., 1993). The leads in the Fylla complex occur at the intersection of the mid-Cretaceous and Paleocene fault trends.

Upper Paleccene and Lower Eocene mudstones overlie a pronounced unconformity that truncates the crests of the fault blocks, and form the regional top seal. The mudstonedominated Kangeq sequence probably provides a local seal within individual fault blocks. 


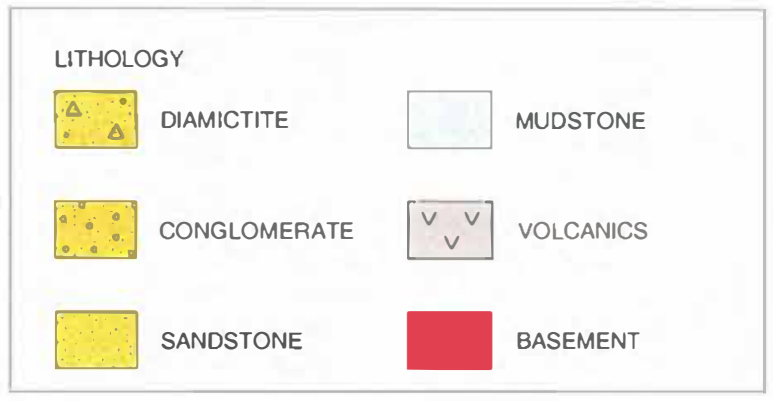

LITHOLOGY
NON DEPOSITIONAL HIATUS
EROSIONAL. HIATUS
(R) POTENTIAL RESERVOIR ROCK
(S) MAJOR POTENTIAL SOURCE ROCK
MINOR POTENTIAL SOURCE ROCK
GEAD OIL

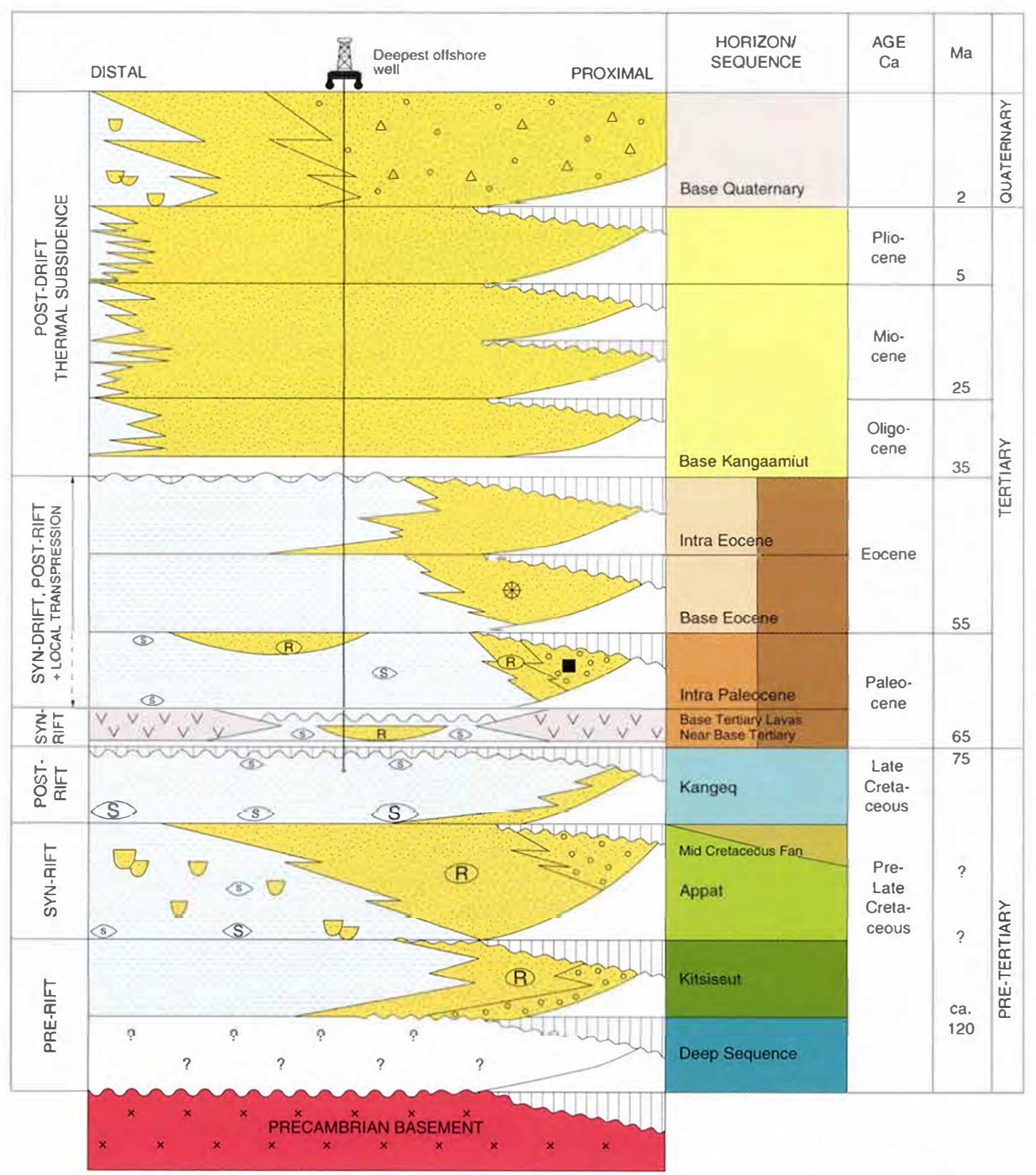

Fig. 4. Generalised lithology and stratigraphy with presumed source and reservoir rocks in the areal of the Fylla structural complex. 


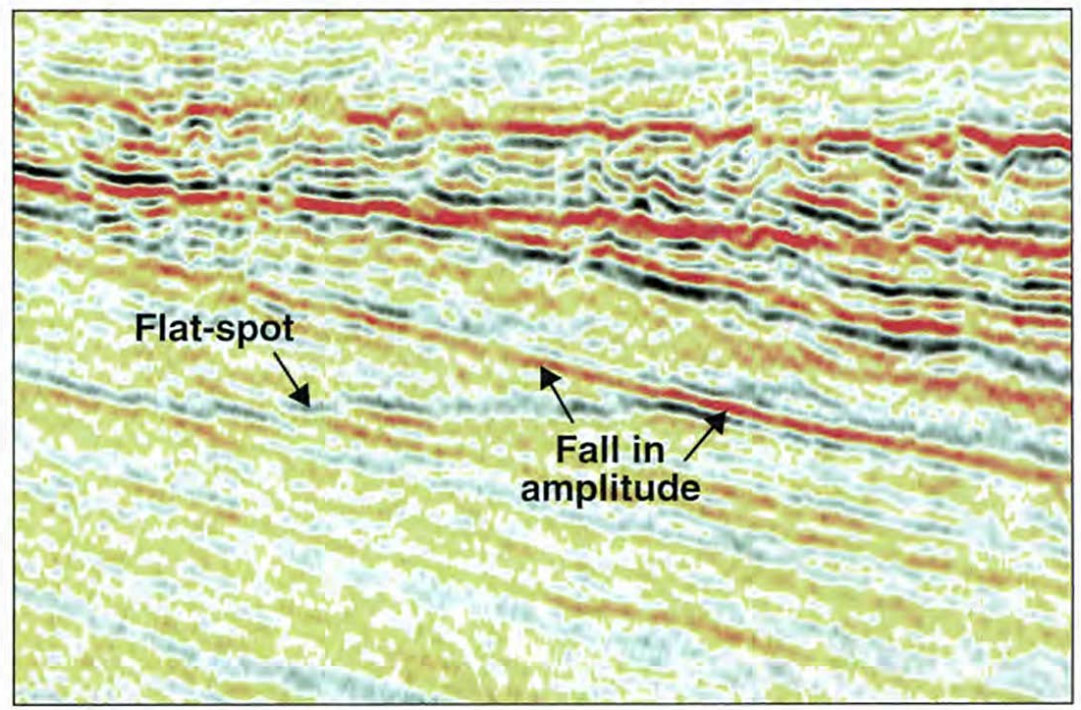

Fig. 5. Flat-spot within one of the fault blocks in the Fylla structural complex.

\section{Source rocks}

Two of the wells drilled of sshore in the 1970) intersected Upper Paleocene to L.ower Eocene gas-prone mudstones with Total Organic Carbon (TOC) values greater than 2\% (Rolle, 1985). This section is believed to extend into the Fylla area, where however, it is relatively thin. Similar TOC values extend into mudstones in the upper part of the Kangey sequence. Maturity modelling suggests that these gas-prone mudstones are immature for hydrocarbon generation in the area of the Fylla complex and are therefore unlikely to be the source rock for any hydrocarbons in the structures.

The global highstand in the Cenomanian-Turonian may have influenced deposition of the lowermost section of the Kangey sequence (Chalmers et al.. 1993). Prolific source rocks are associated with this highstand in a number of areas of the world. An indication that such a source rock could be present offshore West Greenland has recently been provided by Rock-Eval analysis of the late Cenomanian to Maastrichtian Kanguk Formation in the Sverdrup Basin, Canadian Arctic Islands (Núnez-Betelu, 1993). A 10-25m section near the base of the formation consists of black marine mudstones deposited in an open marine environment, during a highstand of sea-level that gave rise to the lirst transgression which spread outside the Sverdrup Basin (Embry. 1991). The TOC values generally average $3 \%$, but locally rise to an average of $7 \%$, the increase in TOC generally being accompanied by a rise in the Hydrogen Indices to 225-55(). The combination of a high TOC content with high Hydrogen Indices indicates good oil-prone source potential.

The possibility that a similar oil-prone source interval may extend south into southern offshore West Greenland cannot be discounted. A hypothetical Cenomanian-Turonian source may be marginally mature to just post-mature for oil in a kitchen north of the Fylla complex, and may be the source of any oil in the leads. Charging the Fylla complex from this kitchen would require migration across an intervening faulted area.

Source rocks capable of generating oil have not been directly identified offshore West Greenland, although the discovery in 1993 of an oil seep at Marraat on the Nuussuac peninsula (Fig. I) indicates that an oil-prone source rock must exist in this region (Christiansen et al., 1994a). The Marraat oil contains a relatively high amount of oleanane, a compound that is characteristic of oils generated in latest Cretaceous (o Tertiary deltas (Christiansen et al., 1994b).

Coals and perhaps lacustrine mudstones within the Appat and Kitsissut sequences are likely to be the main source for gas within the Fylla complex. Such lithologies are present within the Bjarni Formation on the Labrador Shelf, and are the source for the gas in the Bjarni and North Bjarni gas fields, offishore Labrador (McWhae et cl., 1980). If similar source rocks are present within the Kitsissut and Appat sequences these are likely 10 be mature for gas generation in and around the Fylla structural complex. A major question remains as to whether the volume of coal needed to give rise to the amount of gas could be present in the complex. However, additional sources may be near at hand. A gravity low south of the area may indicate a further sedimentary basin and a potential kitchen capable of charging the Fylla complex with both gas and oil. Unfortunately this area is beyond the present seismic coverage.

\section{Direct hydrocarbon indicators}

The suggestion that the Fylla structural complex contains large amounts of gas is based primarily on the presence of Iwo flat-spots within the Appat sequence on one of the seis- 
mic lines. This line has been reprocessed by Simon Petroleum Technology Ltd to evaluate these anomalies and to ascertain if they could represent a gas-liquid contact (Fig. 5).

The flat-spots lie above the first seabed multiple. Interbed multiples were suppressed by the use of a Tau-P demultiple process followed by deconvolution before stack, and the resultant autocorrelations show little or no residual multiples. The data were then converted to zero phase with the use of the Thompson multitaper technique before being stacked and migrated.

The results of the reprocessing indicate that the flat-spots are unlikely to be multiples and that velocities are consistent with the primary reflections around them. The AVO character shows a persistent increase in reflection amplitude with offset. A further significant observation is that the strength of the reflector forming the stratigraphic top of the flat-spot layer weakens as it passes from below to above the level of the flat-spot (Fig. 5). All of these factors are consistent with the suggestion that the flat-spots represent a gas-liquid contact.

Flat-spots are distinct in two of the fault blocks in the Fylla structural complex and a weak flat-spotcan be seen in a third. There are a number of other fault blocks where the stratigraphic interval crossed by the flat-spot occurs in a trap configuration, and if a gas-liquid contact is the explanation of the flat-spots, gas may also be expected in these. The possibility that significant oil reserves are present below a gas column cannot be discounted.

Unfortunately the seismic grid used over the complex is open, and the extent of traps along the strike of the fault blocks could only be roughly estimated during the interpretation phase. Detailed structural maps and hence accurate reserve estimates are at present not possible. For two of the structures, the estimate of gas in place is based on a single seismicline through the lead. However, during the 1994 field season the Greenlandic/Danish state oil company, Nunaoil A/S, acquired $1708 \mathrm{~km}$ of new seismic data forming a tighter grid over the Fylla complex (Fig. 2). These data are currently being processed, and the results may delineate the leads more accurately.

With these reservations taken into account, a preliminary estimate for the total volume of gas in place for each lead in the Fylla structural complex has been calculated. In all calculations the sand/shale ratio is assumed to be $50 \%$ and the average porosity $20 \%$. The gross rock volume within each structure was calculated using the appropriate formulae and assuming a water saturation $\left(\mathrm{S}_{\mathrm{w}}\right)$ of $30 \%$. As only gas is thought to be present above the flat-spots, the figures arrived at refer only to gas and have been calculated by multiplying the pore volume by $70 \%$ for the $1-S_{w}$ and multiplying the product by an expansion factor of 275 to bring the gas to normal temperature pressure (NTP). The resulting estimate for the total volume of gas in the Fylla structural complex as a whole is of the order of $100 \mathrm{tcf}$, comparable in size to the Groningen gas field of the Netherlands. These very large potential gas reserves, plus the possibility of additional oil reserves in considerable quantities, mean that the Fylla structural complex is a potentially attractive exploration target.

\section{References}

Balkwill, H. R. 1987: Labrador Basin: structural and stratigraphic style. In Beaumont, C. \& Tankard, A. J. (ed.) Sedimentary basins and basin-forming mechanisms. Mem. Can. Soc. Petrol. Geol. 12, 17-43.

Balkwill, H. R., McMillan, N. J., MacLean, B., Williams, G. L. \& Srivastava, S. P. 1990: Geology of the Labrador Shelf, Baffin Bay, and Davis Strait. In Keen, M. J. \& Williams, G. L. (ed.) Geology of the continental margin of eastern Canada, 293-348. Geology of North America I-1 (also Geology of Canada 2, Geological Survey of Canada). Boulder, Colorado: Geological Society of America.

Chalmers, J. A. 1991: New evidence on the structure of the Labrador Sea/Greenland continental margin. J. geol. Soc. London 148, 899-908.

Chalmers, J. A., Pulvertaft, T. C. R., Christiansen, F. G., Larsen, H. C., Laursen, K. H. \& Ottesen, T. G. 1993: The southern West Greenland continental margin: rifting history, basin development, and petroleum potential. In Parker, J. R. (ed.) Petroleum geology of North West Europe: Proceedings of the 4th Conference, 915-931. London: Geological Society.

Christiansen, F. G., Dam, G. \& Pedersen, A. K. 1994a: Discovery of live oil at Marraat, Nuussuaq: fieldwork, drilling, and logging. Rapp. Grønlands geol. Unders. 160, 57-63.

Christiansen, F. G., Bojesen-Koefoed, J. \& Nytoft, H. P. 1994b: Organic geochemistry of oil-impregnated cores from the Marraat-1 well, Nuussuaq, West Greenland - comparison with surface samples. Open File Ser. Grønlands geol. Unders. 94/8, 26 pp.

Embry, A. F. 1991: Mesozoic history of the Arctic Islands. In Trettin, H. P. (ed.) Geology of the Innuitian orogen and arctic platform of Canada and Greenland, 263-279. Geology of Canada 3 (also Geology of North America E). Calgary: Geological Survey of Canada.

McWhae, J. R. H., Elie, R., Laughton, K. C. \& Gunther, P. R. 1980: Stratigraphy and petroleum prospects of the Labrador Shelf. Bull. Can. Petrol. Geol. 28, 460-488.

Núñez-Betelu, L. K. 1993: Rock-Eval/TOC pyrolysis data from the Kanguk Formation (Upper Cretaceous), Axel Heiberg and Ellesmere Islands, Canadian Arctic. Open File Rep. Geol. Survey Canada 2727, 29 pp.

Rolle, F. 1985: Late Cretaceous-Tertiary sediments offshore central West Greenland: lithostratigraphy, sedimentary evolution, and petroleum potential. Can. J. Earth Sci. 22, 1001-1009.

K. J. B., R. C. W. \& J. A. C., Geological Survey of Denmark and Greenland, Copenhagen

T. D.-J., Geological Survey of Denmark and Greenland. Present address: Danish Lithosphere Centre, Øster Voldgade 10, DK1350 Copenhagen K, Denmark 